\title{
RANCANG BANGUN SISTEM PENDATAAN PENDUDUK BERBASIS WEBSITE DI NEPA SAMPANG
}

\author{
Abdur Rohman', Ima Kurniastuti², Ahmad Syafiq Kamil ${ }^{3}$ \\ Program Studi Sistem Informasi, Fakultas Teknik, Universitas Nahdlatul Ulama Surabaya \\ 1abdurrohmananipani96@gmail.com, ${ }^{2}$ ima.kurniastuti@unusa.ac.id, ${ }^{3}$ ahmadsyafiqkamil@unusa.ac.id
}

\begin{abstract}
Abstrak
Menurut Undang-Undang No 6 Tahun 2014, Pemerintah Pusat menuntut pemerintahan tingkat desa untuk meningkatkan kualitas layanan penduduk dengan mengubah sistem penyelenggaraan pelayanan administrasi desa dari konvensional menjadi digital. Oleh karena itu dalam penelitian ini dilakukan rancang bangun sistem pendataan penduduk berbasis web di Desa Nepa Kecamatan Banyuates Kabupaten Sampang. Diharapkan sistem pendataan penduduk berbasis web ini mempermudah perangkat desa dalam mendata penduduk dan pelaporan ke pemerintah tingkat kecamatan setiap bulannya. Tahapan yang dilakukan diantaranya identifikasi masalah, identifikasi kebutuhan sistem, desain sistem, implementasi, pengujian sistem, serta validasi. Desain sistem meliputi flowchart, entity relationship diagram, use case diagram, sequence diagram, class diagram dan desain antar muka. Hasil validasi menunjukkan sistem pendataan penduduk tidak ada kesalahan dan berjalan sesuai kebutuhan serta pengguna memberikan respon positif pada saat penggunaan sistem.
\end{abstract}

Kata kunci : website, sistem pendataan penduduk, bahasa pemrograman PHP, web

\section{Pendahuluan}

Berdasarkan Undang-Undang No.6 Tahun 2014 tentang peningkatan kualitas layanan penduduk, Pemerintah Pusat menuntut perangkat pemerintahan di tingkat desa atau kelurahan untuk mengubah sistem penyelenggaraan pelayanan administrasi desa dari konvensional menjadi berbasis digital (Indonesia, 2014). Salah satu perangkat pemerintahan tingkat desa yang melakukan perubahan sistem tersebut adalah perangkat Desa Nepa Kecamatan Banyuates Kabupaten Sampang. Perangkat Desa Nepa menyediakan beberapa pelayanan diantaranya pelayanan pembuatan surat dan pencatatan data seperti data penduduk, data Kartu Keluarga (KK), data kelahiran, data kematian, data mutasi (penduduk pindah atau masuk), data penduduk sementara, rekapitulasi jumlah penduduk bulanan dan data agenda pengurusan surat. Dalam penyelenggaraan pelayananan administrasi desa, perangkat Desa Nepa melakukannya secara manual yaitu mencatat pada buku. Hal ini mengakibatkan saat pencarian data penduduk membutuhkan waktu yang lama dan dapat terjadi kehilangan data yang diakibatkan oleh kerusakan atau hilangnya buku. Dalam proses pelaporan yang dilakukan setiap bulan ke Dinas Pencatatan Sipil, perangkat desa juga mengalami kesulitan dikarenakan perangkat desa harus menyalin data satu per satu menggunakan aplikasi pengolah data seperti Microsoft Excel.

Untuk mengatasi permasalahan tersebut, perlu dibangun suatu aplikasi website yang dapat membantu perangkat desa dalam melakukan pencatatan data, agenda pengurusan surat serta pengolahan dan pelaporan data kependudukan dengan cepat dan akurat sehingga dapat mempermudah dan meningkatkan kualitas pelayanan kependudukan di Desa Nepa. Selain itu, sistem pendataan penduduk berbasis web ini diharapkan dapat mempermudah perangkat desa dalam mendata penduduk dan pelaporan ke pemerintah tingkat kecamatan setiap bulannya. Metode yang digunakan untuk membangun website system pendataan penduduk adalah model siklus hidup pengembangan system waterfall. Website di rancang bangun menggunakan pemodelan UML dan PHP sebagai bahasa pemrogramannya serta penyimpanan database dilakukan secara lokal. Hal ini disebabkan karena kondisi jaringan internet di Desa Nepa yang kurang memadai.

PHP merupakan salah satu dari lima bahasa pemograman yang paling umum digunakan di dunia (Li, 2015). PHP cocok diimplementasikan untuk merancang aplikasi website yang dinamis (Nguyen, 2013). Selain itu, PHP merupakan bahasa pemrograman yang tidak memerlukan biaya, dapat diimplementasikan pada website mulai skala kecil hingga besar, dapat digunakan pada semua system operasi, memiliki banyak kesamaan dengan bahasa pemrograman $\mathrm{C}$ sehingga memudahkan pengguna dalam pengoperasiannya, serta pengembangan bahasa pemrograman PHP yang terus berjalan (Yu,2010). Ketika dibandingkan dengan bahasa pemrograman Java dan C, PHP memberikan performa tinggi dalam menyediakan pelayanan 
produktifitas perangkat lunak yang tinggi (Suzumura, 2008).

Aplikasi website sistem informasi pendataan penduduk telah banyak dirancang dan dibangun oleh peneliti-peneliti lain. Haswan (2018) merancang website sistem informasi pendataan penduduk kelurahan sungai jering menggunakan object oriented programming. Website tersebut hanya menyediakan pencatatan data penduduk dan pelaporan data penduduk saja. Penelitian yang dilakukan oleh Idris (2017), merancang bangun sebuah sistem informasi manajemen satu atap berbasis web GIS (Geographic Information System). Sistem yang dibangun adalah sistem pendataan penduduk yang terdiri dari proses pendataan penduduk, kartu keluarga $(\mathrm{KK})$, surat kelahiran, surat kematian dan surat keterangan pindah. Sistem tersebut juga dilengkapi dengan sistem GIS sehingga dapat menunjukkan letak geografis desa secara langsung secara dinamis dan akurat dalam waktu singkat. Namun sistem ini tidak cocok diimplementasikan di Desa Nepa dikarenakan jaringan internet di Desa Nepa masih belum tersedia. Oleh karena itu, pada penelitian ini dilakukan rancang bangun aplikasi sistem pendataan kependudukan berbasis website dengan akses dilakukan secara local access. Sistem diharapkan dapat memudahkan perangkat desa dalam melakukan pelaporan data kependudukan untuk memperkecil kemungkinan terjadinya kesalahan dalam melakukan pedataan dan pelaporan dan penduduk di desa Nepa. Selain itu, sistem yang dibangun lengkap mulai dari pendataan penduduk, pengurusan surat hingga rekapitulasi jumlah penduduk. Sistem diakses secara local access disebabkan jaringan internet di Desa Nepa yang belum tersedia.

\section{Landasan Teori \\ 2.1 Pendataan penduduk}

Dalam Undang-Undang Republik Indonesia Nomor 23 Tahun 2006 tentang administrasi kependudukan dijelaskan bahwa Penduduk adalah Warga Negara Indonesia dan Orang Asing yang bertempat tinggal di Indonesia. Kependudukan adalah hal ihwal yang berkaitan dengan jumlah, struktur, umur, jenis kelamin, agama, kelahiran, perkawinan, kehamilan, kematian, persebaran, mobilitas dan kualitas serta ketahanannya yang menyangkut politik, ekonomi, sosial, dan budaya (Indonesia, 2006).

\subsection{SDLC (Software Development Life Cycle)}

Model waterfall adalah suatu proses pengembangan perangkat lunak berurutan, di mana kemajuan suatu sistem dipandang sebagai suatu hal yang terus mengalir ke bawah (seperti air terjun) melewati fase-fase perencanaan, pemodelan, implementasi konstruksi) dan pengujian (Pressman, 2002).

\subsection{Bahasa Pemrograman PHP}

PHP meruapakan kependekan dari (PHP HypertText Preprocessor), yang merupakan bahasa utama script server side yang disisispkan pada HTML yang dijalankan di server, dan juga bisa digunakan untuk membuat aplikasi desktop (Sidik, 2014) selain itu penggunaan PHP memungkinkan web dapat dibuat dinamis sehingga maintenance situs web tersebut menjadi lebih mudah dan efisien (Peranginangin,2006). Selain itu menurut (Hakim, 2010) PHP merupakan Software Open-source yang disebarkan dan dilisensikan secara gratis serta dapat di download secara bebas di situs resminya. PHP ditulis menggunakan bahasa $\mathrm{C}$.

\section{Metodologi}

Metode yang digunakan dalam penelitian ini adalah waterfall. Dengan metode waterfall, pengerjaan dari rancang bangun sistem dilakukan secara berurutan atau secara linear. Tahapan penelitian ditunjukkan pada Gambar 1. Pada tahapan pertama yaitu identifikasi masalah, Teknik pengumpulan data yang digunakan adalah wawancara, observasi dan studi literatur. Pada tahapan identifikasi kebutuhan sistem, dilakukan Analisa kebutuhan sistem lama yang dibutuhkan untuk mendukung keberhasilan terhadap proses pembangunan sebuah aplikasi.

Pada tahapan selanjutnya yaitu tahap desain sistem yang dilakukan desain atau pemodelan terhadap struktur data, arsitektur perangkat lunak, representasi antarmuka dan desain logika berupa design alur berjalannya sistem dengan menggunakan pemodelan UML yaitu Flowchart, Entity Relationship Diagram, Use Case Diagram, Squence Diagram, Class Diagram. Tool yang dibutuhkan pada tahapan ini diantaranya Microsoft Visio dan Rational Rose.

Pada tahap implementasi, dilakukan proses menerjemah ke dalam bahasa pemrograman dari hasil desain pada tahap sebelumnya melalui proses coding. Proses pengembangan aplikasi pada penelitian ini dilakukan dari awal hingga aplikasi siap dijalankan serta fungsi-fungsi dan tampilan berjalan sebagaimana mestinya sesuai dengan kebutuhan sistem. Pada tahap pengujian sistem dilakukan pengujian terhadap proses coding yang sudah selesai. Metode pengujian yang digunakan yaitu metode pengujian white box testing dan black box testing. Pada pengujian white box testing dilakukan pengecekan terhadap alur logika program dengan melihat langsung source code program dan mencoba untuk menemukan kesalahan, bug atau error dari kode program yang telah dibuat. Pengujian black box testing dilakukan pengecekan dengan membuat suatu test case untuk melihat kesesuaian alur kerja fungsional aplikasi sesuai apa yang dibutuhkan oleh pengguna dalam hal ini perangkat desa. Tahap 
Validasi sistem dilakukan presentasi hasil pembangunan aplikasi kepada perangkat desa dan dilakukan penilaian terhadap hasil pembangunan aplikasi apakah sudah sesuai atau tidak dengan kebutuhan pengguna. Metode yang digunakan adalah UAT (User Aceptance Test), sebuah testing yang dijalankan untuk mengetahui apakah masih terdapat defect pada aplikasi atau software yang dikembangkan. Fokus pada UAT adalah pada fungsi dan kegunaan aplikasi daripada aspek teknis. Pengujian UAT dilakukan dengan menggunakan metode wawancara yang terdiri dari beberapa pertanyaan terkait aplikasi. Narasumber yang menjadi sasaran dalam hal ini adalah perangkat desa yang akan menilai apakah aplikasi sudah sesuai atau tidak dengan kebutuhan yang diharapkan. Hasil pengujian adalah sebuah dokumen yang dijadikan bukti bahwa sistem yang dibangun sudah layak dan bisa untuk diterapkan (Efy, 2016).

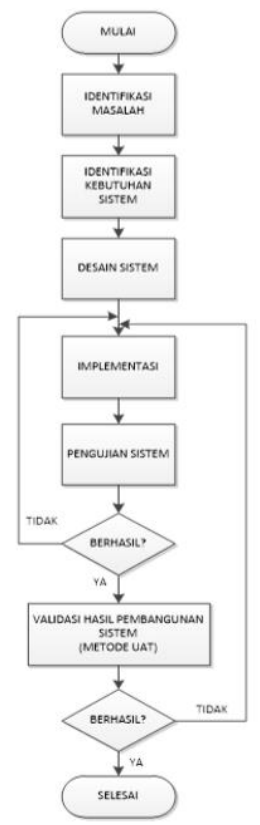

Gambar 1. Tahapan metodologi penelitian

\section{Hasil dan Pembahasan \\ 4.1 Identifikasi Masalah}

Dengan teknik pengumpulan data berupa wawancara, observasi dan studi literatur pada perangkat desa, didapatkan alur pelayanan kependudukan yang sedang berjalan saat ini di Desa Nepa Kecamatan Banyuates Kabupaten Sampang yang ditunjukkan pada Gambar 2 hingga Gambar 4.

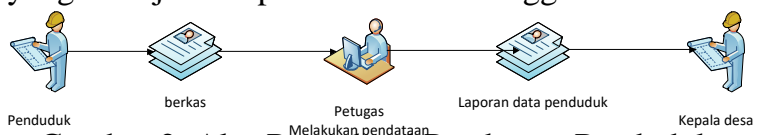

Gambar 2. Alur Prosedural Pendataan Penduduk

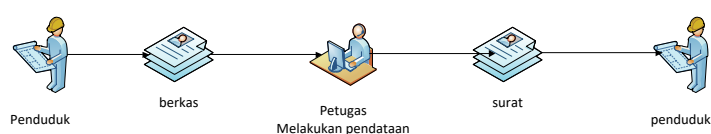

Gambar 3. Alur Prosedural Pengurusan Surat

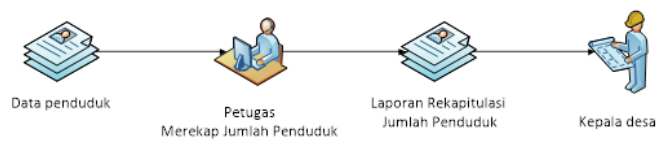

Gambar 4 Alur Prosedural Rekapitulasi Jumlah Penduduk

\subsection{Flowchart}

Pada desain flowchart terdapat sembilan flowchart yang terdiri dari flowchart proses pendataan data penduduk, flowchart proses pendataan data kartu keluarga (KK), flowchart proses pendataan data kelahiran, flowchart proses pendataan data kematian, flowchart proses pendataan data pendaftaran eKTP, flowchart proses pendataan data penduduk sementara, flowchart proses pendataan data penduduk pindah, flowchart proses pendataan data penduduk datang, serta flowchart proses pendataan data rekapitulasi jumlah penduduk. Pada Gambar 5 menunjukkan flowchart proses pendataan data penduduk.

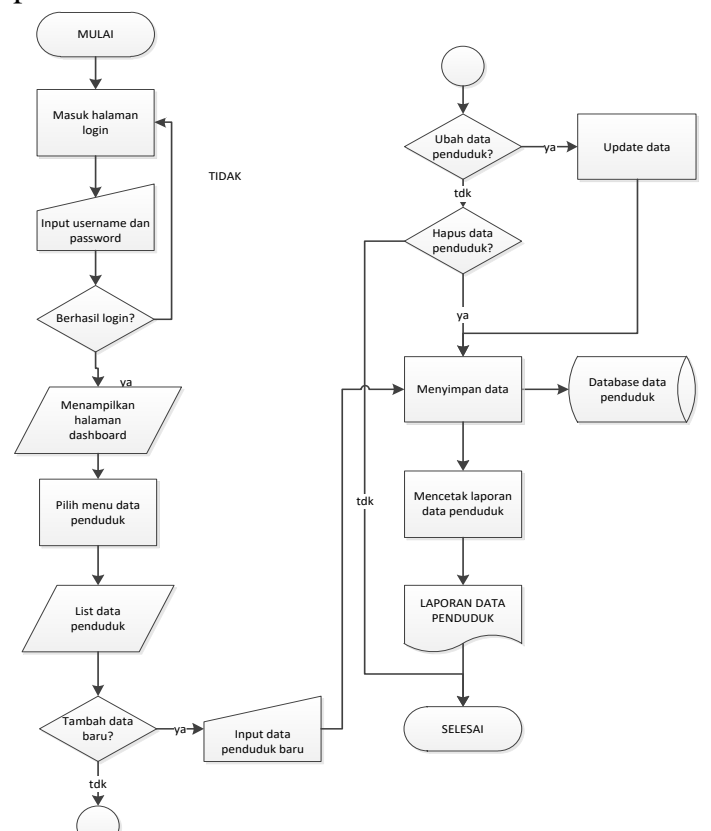

Gambar 5. Alur Proses Pendataan Data Penduduk

\subsection{Use Case Diagram}

Use case diagram menggambarkan fungsionalitas yang diharapkan dari sebuah sistem dengan penekanan apa yang dilakukan oleh sistem. Use case diagram sistem pendataan penduduk ditunjukkan pada Gambar 6.

\subsection{Sequence Diagram}

Pada penelitian ini terdapat sepuluh sequence diagram diantaranya sequence diagram login, sequence diagram tambah data penduduk, sequence diagram tambah data kartu keluarga, sequence diagram tambah data kelahiran, sequence diagram 
tambah data kematian, sequence diagram tambah data pendaftaran e-KTP, sequence diagram tambah data penduduk sementara, sequence diagram tambah data penduduk pindah, sequence diagram tambah data penduduk datang, dan sequence diagram tambah data rekapitulasi jumlah penduduk. Pada Gambar 7 menunjukkan sequence diagram pada tambah data penduduk.

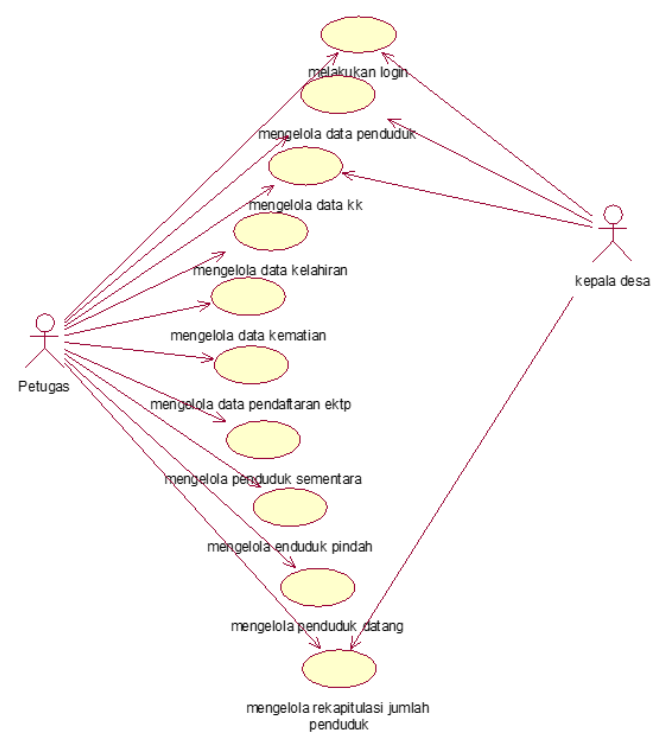

Gambar 6. Use Case Diagram Sistem Pendataan Penduduk

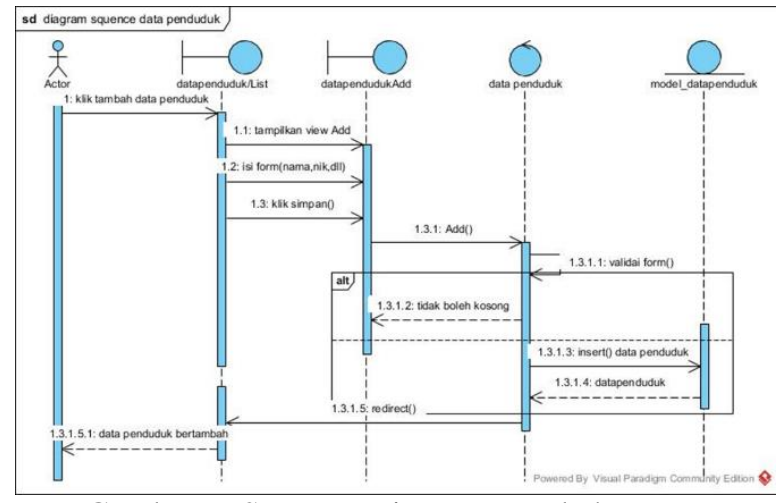

Gambar 7. Squence Diagram Tambah Data

Penduduk

\subsection{Activity Diagram}

Pada penelitian ini terdapat 19 activity diagram diantaranya activity diagram login, activity diagram mengelola akun pengguna, activity diagram mengelola data penduduk, activity diagram mengelola data kartu keluarga, activity diagram mengelola data kelahiran, activity diagram cetak surat kelahiran, activity diagram mengelola data kematian, activity diagram cetak surat kematian, activity diagram mengelola data pendaftaran e-KTP, activity diagram cetak surat pendaftaran e-KTP, activity diagram mengelola data penduduk sementara, activity diagram cetak surat domisili, activity diagram mengelola data penduduk pindah, activity diagram cetak surat pindah, activity diagram mengelola data penduduk datang, activity diagram mengelola data rekapitulasi jumlah penduduk, dan activity diagram logout. Pada Gambar 8 menunjukkan activity diagram mengelola data penduduk.

\subsection{Entity Relationship Diagram}

Entity Relationship Diagram menunjukkan relasi antara masing-masing objek yang berada dalam sebuah himpunan dan dilengkapi dengan atributatribur yang menjelaskan fakta dari objek tersebut. Gambar 9 menunjukkan entity relationship diagram sistem pendataan penduduk.

\subsection{Class Diagram}

Class diagram menggambarkan struktur dari kelas-kelas yang digunakan untuk membangun sistem pendataan penduduk. Gambar 10 menunjukkan class diagram sistem pendataan penduduk.

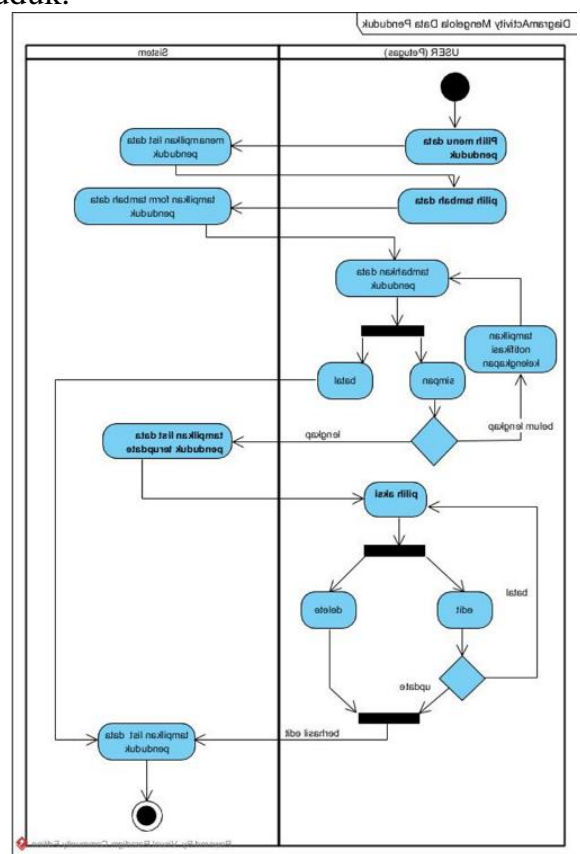

Gambar 8. Activity Diagram Mengelola Data Penduduk

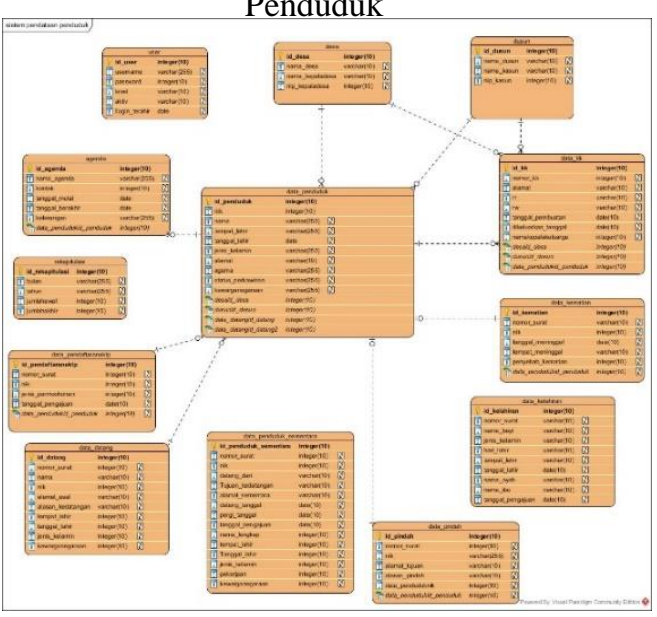

Gambar 9. ERD sistem pendataan penduduk 


\subsection{Desain Antar Muka}

Desain antar muka merupakan rancangan yang akan digunakan sebagai perantara user dengan perangkat lunak yang dikembangkan. Desain antar muka menjadi acuan bagi programmer dalam melakukan pengembangan sistem pendataan penduduk. Pada penelitian ini terdapat 7 desain antar muka diantaranya form login sistem, halaman dashboard, halaman form input data, halaman form edit data, halaman list data, halaman laporan data penduduk dan halaman cetak surat. Gambar 11 menunjukkan halaman form input data.

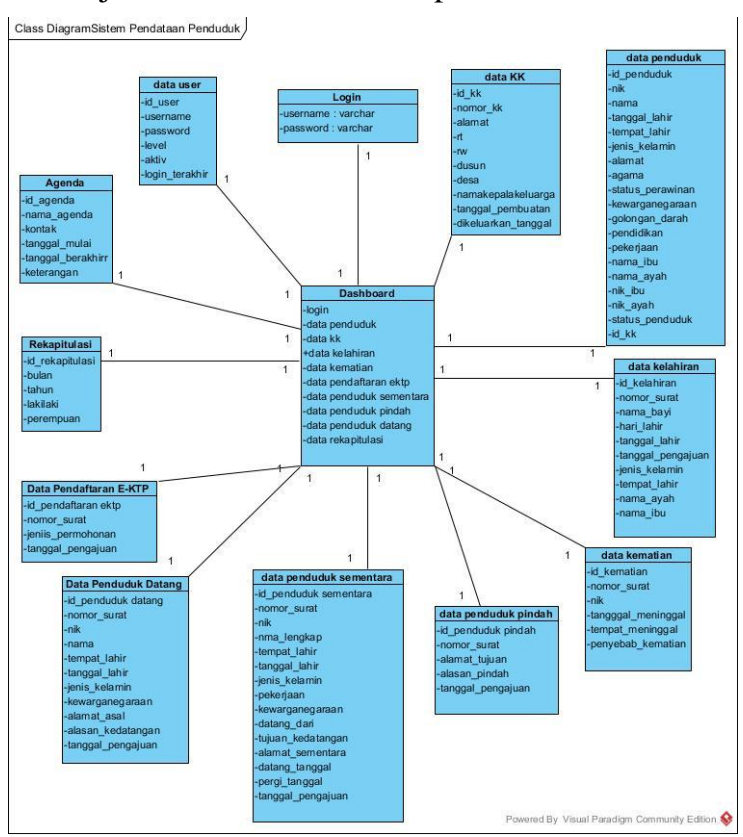

Gambar 10. Class diagram sistem pendataan penduduk

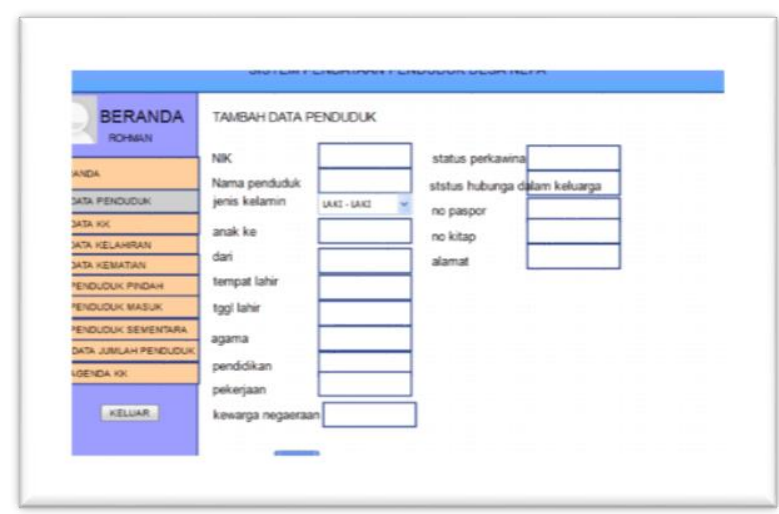

Gambar 11. Desain antar muka halaman form input data

\subsection{Implementasi}

Pada tahap ini dilakukan proses pembangunan sistem berupa pengkodean ke dalam Bahasa pemrograman berdasarkan perancangan dan desain sistem yang telah dilakukan sebelumnya. Pada tahap ini, terbagi menjadi dua bagian yaitu implementasi basis data dengan memanfaatkan aplikasi XAMPP dan implementasi pengkodean. Implementasi basis data bertujuan untuk membuat database dari sistem pendataan penduduk. Implementasi pengkodean dilakukan untuk membuat kode program berdasarkan desain arsitektur sistem ke dalam bahasa pemrograman PHP.

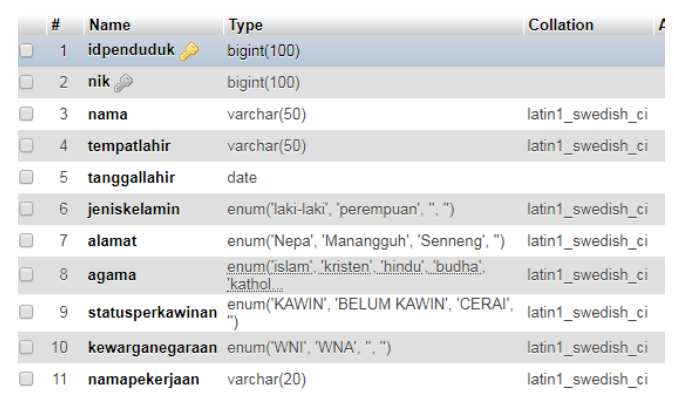

Gambar 12. Implementasi basis data berupa table data penduduk

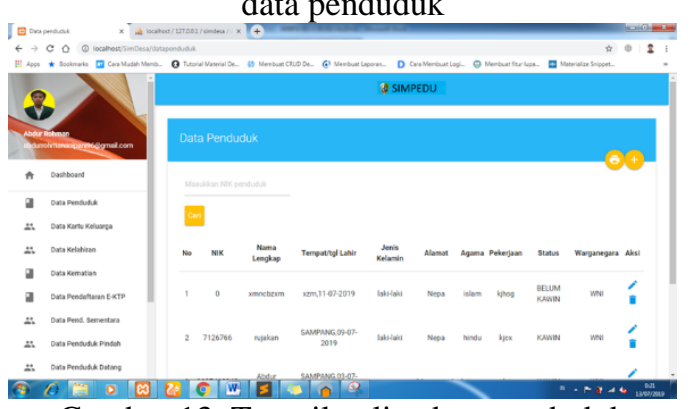

Gambar 13. Tampilan list data penduduk

\subsection{Pengujian Sistem}

Pada tahap ini dilakukan pengujian terhadap sistem yang telah dibangun. Metode pengujian sistem yang digunakan ada dua yaitu black box testing dan white box testing. Black box testing berfokus pada mencari kesalahan program secara fungsionalitas sedangkan white box testing dilakukan pengujian berdasarkan pada struktur internal program untuk mengecek apakah terdapat alur yang error. Hasil pengujian sistem menggunakan black box testing menunjukkan bahwa sistem pendataan penduduk secara fungsional sesuai dengan skenario yang dirancang dan sesuai kebutuhan. Hasil pengujian sistem menggunakan white box testing menunjukkan jumlah cyclomatic complexity sesuai dengan alur program yang dirancang.

\subsection{Validasi Sistem}

Pada tahap ini dilakukan presentasi hasil aplikasi dan pengujian penerimaan aplikasi dengan melibatkan pengguna untuk menggunakan aplikasi sekaligus memberikan penilaian subjektif terhadap aplikasi. Pada pengujian ini menggunakan pengujian UAT (User Aceptance Test) dengan pendekatan metode TAM (Technology Acceptance Model). Pengujian ini menggunakan dua variabel penilaian yaitu Usefullness dan Ease of Use. Hasil pengujian 
UAT dengan pendekatan model TAM dan 2 variabel yaitu Perceived Usefullness dan Perceived Ease of Use menunjukkan pengguna setuju dengan manfaat yang diperoleh dari penggunaan sistem pendataan penduduk dan pengguna merasa layout dan tampilan Sistem Pendataan Penduduk Desa Nepa sesuai dengan yang diharapkan seperti penempatan tombol, penataan menu, komposisi warna dan tampilan font membuat pengguna mudah dalam mempelajari penggunaan Sistem Pendataan Penduduk Desa Nepa.

\section{Kesimpulan}

Dalam penelitian ini dilakukan perancangan dan pembangunan sistem pendataan penduduk berbasis web di Desa Nepa Kecamatan Banyuates Kabupaten Sampang dengan tahapan-tahapan diantaranya identifikasi masalah, identifikasi kebutuhan sistem, desain sistem, implementasi, pengujian sistem, serta validasi. Tahap perancangan sistem dilakukan hingga tahap desain sistem sedangkan tahap pembangunan sistem dilakukan dari tahap implementasi hingga validasi. Hasil validasi menunjukkan sistem pendataan penduduk tidak ada kesalahan dan berjalan sesuai kebutuhan serta pengguna memberikan respon positif pada saat penggunaan sistem.

\section{Daftar Pustaka}

Efy, Widyawati A. K. (2016). Rancang Bangun Aplikasi Kependudukan Berbasis Web di Desa Kedungrejo. Jurnal Manajemen Informatika Volume 6 No.1 Tahun 2016.

Hakim, Lukmanul. (2010). Membangun Web Berbasis PHP dengan Framework Codeigniter. Yogyakarta : Lokomedia.

Haswan, Febri. (2018). Perancangan Sistem Informasi Pendataan Penduduk Kelurahan Sungai Jering Berbasis Web dengan Object Oriented Programming. Jurnal Teknologi dan Open Source. Volume 1 No. 2 Desember 2018.
Idris, Muhammad. Hariyanto, Rudi. Widodo, Anang Aris. (2017). Rancang Bangun Sistem Informasi Manajemen Satu Atap (SIMTAP) Berbasis Web GIS (Geographic Information System). Journal of Information Technology and Computer Science (JOINTECS). Volume 2 No.2, Agustus 2017.

Indonesia, Kementerian Keuangan Republik. (2014). Undang-Undang Republik Indonesia No.6 Tahun 2014 Tentang Desa. Retrieved from https://jdih.kemenkeu.go.id

Indonesia, Kementerian Hukum dan HAM Republik. (2006). Undang-Undang Republik Indonesia Nomor 23 Tahun 2006 tentang Administrasi Kependudukan. Li, Xiangyi. Li, Yanheng. (2015). The Application of Three-Phase Project Teaching in PHP Programming Design. Paper presented at The 2015 5th International Conference on Information Science and Technology (ICIST). Changsha, China.

Nguyen, Hung Viet. Nguyen, Hoan Anh. Nguyen, Tung Thanh. Nguyen, Tien N. (2013). DRC: A Detection Tool for Dangling References in PHPBased Web Applications. Paper presented at The 2013 35th International Conference on Software Engineering (ICSE), San Fransisco, California, USA. Paranginangin, Kasiman. (2006). Aplikasi WEB dengan PHP dan MySQL. Yogyakarta: Andi.

Pressman Roger S. (2002). Rekayasa Perangkat Lunak. Yogyakarta: Andi Publishing.

Sidik, Betha. (2014). Pemrograman Web PHP. Bandung : Informatika.

Suzumura, Tyoyotaro. Trent, Scott. Tatsubori, Michiaki. Tozawa, Akihko. Onodera, Tamiya. (2008). Performance Comparison of Web Service Engines in PHP, Java and C. Paper presented at The 2008 IEEE International Conference on Web Services. Beijing, China.

Yu, Xiaosheng. Yi, Cai. (2010). Design and Implementation of the Website Based on PHP and MYSQL. Paper presented at The 2010 International Conference on E-Product, E-Service and EEntertainment. Henan, China. 